\title{
Liminalities: expanding and constraining the options of Somali youth in the Helsinki metropolitan area
}

\author{
ANNE ALITOLPPA-NIITAMO \\ M.A. (psych.) \& M.Phil. (applied anthropology) \\ Visiting Scholar \\ The Population Research Institute, \\ The Family Federation of Finland
}

\begin{abstract}
Somali youth, "the generation in-between", who arrived in Finland in their early teens or as teenagers in the 1990s have faced specific challenges in Somali diaspora in Finland. Their voice is often ambiguous in the processes of cultural construction and ethnic reconstruction. Dissonant acculturation and role reversal within the families and a family culture that emphasizes strong parental authority place these young people in a liminal position.Measures which balance the pace of the acculturation between the generations could alleviate the situation
\end{abstract}

In addition, the diasporic consciousness and transnational activities among Somalis along with the ethos of 'integration' within the mainstream institutions challenge Somali youth. They may find themselves 'betwixt and between' various future orientations. This should be acknowledged in educational planning, for example.

While liminal states may open up new opportunities, it is claimed that several simultaneous states of liminality may be confusing for a young person, and may create risks for becoming marginal from societal and cultural classifications, as well as limit a person from finding his/her own group of reference.

Keywords: refugees, second generation, diaspora, ethnic reconstruction, Somali, generation in-between

\section{Introduction}

This article is about Somali youth who arrived in Finland as asylum seekers in the 1990s. Some of them arrived with their parents or caretakers, others came initially as unaccompanied minors. Only a few had a solid educational background, while many had a rather fragmentary history of schooling, and some had no school background at all. 
All of them came from a country devastated by a brutal civil war. At arrival, they and their families were looking for a sanctuary, but also for ways to re-establish their lives. In a new and complex society, many parents directed their hopes and expectations towards their offspring.

Somalis had to assume the role of 'icebreakers' in the Finnish reception system for asylum seekers as well as in the public discourse on refugees. Until the arrival of the first Somalis in 1989 and 1990, few migrants had targeted Finland. In 1988, there were approximately 20,000 persons of foreign nationality living permanently in the country composing less than 0.5 percent of the population. Most immigrants had arrived from Nordic and other European countries, and the largest refugee group prior to the Somalis were the Vietnamese. By the late 1990s, however, the number of persons of foreign nationality had quadrupled. These new immigrants came from Russia, Estonia, other parts of the former Soviet Union, the former Yugoslavia and Somalia.

The first cultural encounters between Finns and Somalis had taken place in the 1980s in the context of international development cooperation. These contacts were limited for the most part to Finns working in Somalia and a few Somalis studying in Finland. These existing networks functioned as a basis for only a limited number of Somalis migrating to Finland. (See also Aallas 1991). Instead, cooperation between Somalia and the former Soviet Union, based on Cold War alliances in the Horn of Africa, eventually linked Finland and Somalia through refugee migration movements. For example, Somali students in the former Soviet Union functioned as links for many Somalis who were looking for a resettlement destination when the crisis broke out in Somalia. Only a few first-wave Somalis, who entered the country between 1990 and 1992, migrated to Finland as a primary destination. Using the route through Moscow, many stopped and remained in Finland, although few had information about Finland. As the Soviet Union underwent its own turmoil and was no longer able to host them, Finland was the closest Western country for the first wave of Somalis. Financial resources, family members' place of residence and reception policies in resettlement countries determined the destination for many Somalis leaving the Soviet Union. Through the official family reunification program and chain migration based on existing social networks, the number of new arrivals increased towards the end of the millenium.

At the end of the millennium, there were approximately 6,200 Somalis $^{1}$ in Finland

\footnotetext{
'This figure indicates the size of the Somali-speaking population in Finland. The term 'Somali' is used in this article to indicate individuals who identify themselves as ethnically Somalis. Their sense of ethnicity is based on the same language and religion, as well as a shared history in a certain geographical region in the Horn of Africa. The majority of ethnic Somalis are/have been citizens of the Republic of Somalia, but they may also belong to Somali ethnic minorities in the neighboring countries (Kenya, Ethiopia and Djibouti). By the end of the millenium, out of approximately 6,200 Somali speaking individuals in Finland, around 1,700 had received Finnish citizenship (Statistics Finland 2000c). The term 'Somalian' indicates persons who are citizens of the Republic of Somalia. Recently, a group of Somalis who trace their origins to Northwestern Somalia prefer to be called 'Somalilanders'. Somaliland is a region in Northwest Somalia which separated from the rest of Somalia and declared its independence. Its independence has not been recognized by the international community, however.
} 
(Statistics Finland 2000b). There is an even gender division among the Somalis (Tilastokeskus 2000b), and the proportion of minors under the age of 18 is approximately 50 percent of all Somalis (3,240 Somali-speaking children in 1999) (Statistics Finland 2000a $)^{2}$. On the importance of research on immigrant children and youth, Alejandro Portes $(1996,1997)$ claims that focus on second-generation migrants is of strategic importance, since the adaptation of the second generation will be decisive for the long-term consequences of current immigration. Although the patterns of adaptation of the first generation may set the stage for the future, it is among the secondgeneration immigrants where the long-term direction of acculturation of ethnic groups will take place.

\section{The aim of the article}

The aim of this article is to describe two aspects found to create dilemmas in the lives of many Somali youth. The article is based on ethnographic research among Somalis in the Helsinki metropolitan area. This article describes two kinds of challenges many Somali youth face which may place them in a state of "liminality' ${ }^{3}$. Liminality is, according to Victor Turner $(1967,1977)$, a state in which persons are out of their structural context and in an ambiguous position. However, liminalities are not regarded here as static states, but rather as transitional phases in which an individual is detached from previous statuses, norms and definitions while not yet being anchored in new ones. In a transitional phase, a person is simultaneously open to new statuses, norms and definitions, and at the same time, (s)he is socially and psychologically vulnerable if not able to define his/her role, status or group of reference.

Adolescence as such is a state of liminality, a period in between childhood and adulthood. Another such state is the status of being a refugee in a new society (Malkki 1995). In addition to these aspects, but nevertheless related to them, Somali youth face other liminalities, two of which are described in this article. One is connected with their status and sense of power within Somali families and ethnic communities, the other with diasporic and transnational consciousness.

While liminal states may open up new opportunities, it is claimed that several simultaneous states of liminality may be confusing for a young person, and may create risks for becoming marginal from societal and cultural classifications, as well as limit a per-

\footnotetext{
${ }^{2}$ The proportion of minors among Somali speakers is much larger than for Finnish or Swedish speakers and also bigger than that in other groups of speakers of foreign languages in Finland. Only Kurds and Albanians come close to the same proportion of minors. (Statistics Finland 2000b).

${ }^{3}$ Somali youth are not a homogenous group of young people with the same ethnic background. Instead, there is a great diversity among them. In terms of their capabilities to overcome challenges in a new society, at least the following background factors are meaningful: (1) whether they arrived as unaccompanied minors or with a biological or social parent; (2) the level of formal education of their parents or caretakers; (3) their own educational level prior to arrival; (4) their age at arrival.
} 
son from finding his/her own group of reference. The article concentrates on Somali youth in the context of their families. Without underestimating the severity of their consequences, the other possible aspects of liminality which are related to contact with Finnish society (for example, experienced discrimination) are not the focus of this article.

\section{Methodology}

The first phase of ethnographic fieldwork, conducted over a three-month period in 1993 in Helsinki, focused on the formation of inter- and intraethnic networks within the emerging Somali community. In terms of intraethnic networks, divisions according to clan lines were deep at the time, and the political situation in Somalia was reflected in social relations among Somalis in Finland. Interethnic networks were still sparse at the time of the research (see Alitolppa-Niitamo 1994).

The next phase of the research, from 1996 to 2000, focused on Somali youth in the contexts of formal education, families and the ethnic group. This research included community-level fieldwork in the form of discussions and interviews with a variety of ethnic group members, authorities and professionals in the field of education, as well as participant observation of various meetings, household interviews and a six-month classroom ethnography in the Helsinki metropolitan area ${ }^{4}$.

The use of the ethnographic method was motivated by the understanding that human actions are based upon different interpretations of social meanings in which various intentions, motives, beliefs, roles and values play an important role. Because these interpretations are constantly constructed and reconstructed - particularly in cases where rapid societal changes take place, as in the case of people in an acculturation process the social world cannot be explained by simple causal relationships, but needs to be described in more complex and dynamic terms. Participation in the social world of Somalis made it possible to get an inside view of various intentions, motives, beliefs,

\footnotetext{
${ }^{4}$ The research process started with visits to six comprehensive schools (each visit lasting from half a day to five days), out of which one upper comprehensive school with a separate immigrant class was selected for the school ethnography. During the entire research process, 18 authorities and school staff members (other than teachers), 17 Finnish teachers, five Somali teachers, 27 Somali community members and two imaams were interviewed or took part in discussions, many of them several times. The core of Somali youth in the context of schooling consisted of four boys and two girls, all students in the same class. The number of Somali youth was gradually expanded to include their peers, siblings and other youth, reaching a total of 19 students ( 11 boys, 8 girls) from 11 to 21 years old. Discussions were held with four fathers and three mothers of these students as well as with many community members in the role of parent or caretaker. In addition to one particular class, where participant observation lasted from December 1997 to June 1998, observation took place also in other school settings, at parent meetings, during many home visits, while running errands with some of the parents, in a visit to the court with one of the students and in seminars and meetings arranged on issues.related to Somalis in Finland. The follow-up of the six students in the core group has taken place in the form of informal get-togethers and occational telephone calls until fall 2000 . An important source for increased understanding and for contextualizing Somalis in Finland was a ten-day visit to Northwestern Somalia (Somaliland) in 1999.
} 
roles and values which structure and direct the actions of Somali youth. Typical for ethnographic research is that the research problem tends to change and develop to some degree as the research process proceeds according to the researcher's experience and acquired knowledge and insight. This happened here also: the original focus on the role of formal mainstream education in the integration of second-generation Somalis, was redefined as describing the specific circumstances of a specific group of young Somalis, i.e. the ones who arrived in the country in their early teens or as teenagers, here called as "a generation in-between". Consequently, as the research focus has shifted, shifts have also occurred in the topics discussed with the informants and in the selection of informants, as well.

\section{Liminalities}

Victor Turner defined liminality as a state in which persons are out of their structural context and in an ambiguous position. He maintained that persons in a state of liminality pass "through a realm that has few or none of the attributes of the past or coming state" $(1967,94)$. Turner characterizes them as they transgress classificatory boundaries as being "neither-this-or-that, here-nor-there, one-thing-not-the-other" and, paradoxically, "both this and that" $(1977,37){ }^{5}$

Malkki (1995) finds the metaphor of "being betwixt and between" to be a particularly apt description of the situation refugees are in: she claims that refugees are a liminal category, both in anthropology and political theory, due to the fact that their classification is difficult since they are "no longer unproblematically citizens or native informants" (7). Krulfeld (1994) also refers to the state of liminality in refugee experience: when one has been uprooted and is moving and relocating, one is detached from an old status while not yet incorporated into a new one. As a refugee, one is in a process of transition from a past that was more orderly and predictable to a future that is new and unpredictable (Krulfeld and Camino 1994). Referring to refugee adolescents, Camino (1994) claims that they have a double liminal status: being a refugee signifies being caught between old and new surroundings, and being an adolescent denotes the state between childhood and adulthood.

It is claimed in this article that many Somali youth face other states of liminality in addition to those of being an adolescent and a refugee. It is claimed that Somali youth,

\footnotetext{
5 Victor Turner borrowed the concept of liminality from the Belgian folklorist Arnold Van Gennep. Van Gennep (referred to in Turner 1977) examined rites de passage in many cultures. He argued that rites of passage have a tripartite processual structure. They accompany every change of place, state, social position and age, and they are marked by three stages: separation, margin (or limen) and re-aggregation. Of the three stages in the process of rites of passage, Turner was particularly interested of the middle, liminal phase, in which persons undergoing a rite of passage are "betwixt-and-between established states of politicojural structure" $(1977,37)$.
} 
and particularly those who arrived in the country in their early teens or as teenagers in the 90s, may find themselves in between multiple definitions, statuses, norms and expectations which make their situation ambiguous and confusing. Based on the ethnographic evidence, two forms of liminality are described here. One is the state of liminality which is connected to their position and status in the processes of cultural construction/ ethnic reconstruction in their family and ethnic group. The second one is the state of liminality connected to the diasporic and transnational consciousness within their ethnic group and the ethos of 'integration' in the receiving society.

First, Somali youth are represented in this article in the process of negotiating cultures. On the basis of this description is the understanding that ethnicity is not just passed from one generation to another, but rather it is reinvented and rediscovered by each generation (Fischer 1986). In order to be 'socially effective' (Barth 1969,13) in a new environment, refugees participate in the process of cultural construction. Cultural construction/ethnic reconstruction goes on both among the first- and the second-generation refugees. Often there is a difference between generations, though, in the speed and the direction of change - a fact which may create intergenerational conflicts in families. It is claimed in this article that Somali youth are in a liminal position due to their status in the process of cultural construction/ethnic reconstruction: the way in which they construct new hybrid forms of cultures is often experienced as threatening by the adult population, while simultaneously the young are needed as guides and sources of information for their parents and caretakers in an unfamiliar and complex society.

Secondly, the diasporic and transnational consciousness among Somalis in Finland is transferred in various degrees also to the younger generations and, according to ethnographic data, many Somali young people seem to construct their imagined futures both in the homeland and in the receiving society. Diasporic and transnational consciousness is described in this article from the point of view of the meanings they accord to formal education. The future perspectives of Somali youth and the meanings of formal education seem to include more than just the ethos of 'integration' which is propagated by the mainstream institutions.

\section{Hybridity and intergenerational conflicts}

\section{Cultural construction/ethnic reconstruction}

Research on youth culture and ethnic culture has increasingly questioned the existence of 'culture' as a bounded, essentialist 'thing' and instead as something blurred, fluid and everchanging (e.g. Abu-Lughod 1991; Werbner 1997). Children and adolescents learn or acquire cultural characteristics which are transferred by their parents or caretakers. But, as Amit-Talal (1995) notes, they cannot simply adopt the cultural repertoires of their parents, instead they engage in a cultural dialogue with the multiplicity of 
forces that represent various values, norms and ways of living. She claims that in order to be 'socially effective' (Barth 1969, 13), young people produce new forms of cultures and in this process they draw elements from various sources including home, school, peers, the street and the media. In a complex society, a multiplicity of circumstances compels youth to intertwine cultural diversity that includes class, gender, ethnicity and locality, as well as transnational influences. Amit-Talal (1995) refers to Clifford $(1988 ; 1)$ by stating that cultural production is multicultural regardless of whether or not the 'exotic' or the exoticized is around the corner. Such terms as bricolage, syncretism and hybridity (Wulff 1995; Caglar 1997; for the origins of the terms, see also Werbner 1997) are used to describe cultural and ethnic mixtures.

Conzen and associates (1992) maintain that every immigrant family comes with its own practices, which it has mixed from remembered and handed-down family, community and regional practices.

Ethnic reconstruction and invention takes place when the already mixed practices are adapted to a new setting in a negotiation, reconstruction and invention process in which advocates of traditionalism, family and community members, as well as the receiving society participate (see also Gans 1997). The multiplicity of voices and practices among the Somalis in Finland, was often connected, however, with some shared cultural characteristics, such as a collective orientation and orality. Also Islam functioned as an important resource for identity construction and value negotiation for most Somalis. (Alitolppa-Niitamo \& Ali 2001)

In the case of immigrant youth, the multiplicity of forces in cultural construction/ethnic reconstruction is even more obvious than in the case of adult immigrants. For young individuals, the active negotiation of one's social identity, space and roles in the new social and cultural context is an everpresent process. Being in the cross-section of many influences provides youth with choice, but it also poses challenges, particularly if expectations coming from various contexts are dissonant with one another. The challenges for identity formation (e.g. Rotheram \& Phinney 1989; Krulfeld \& Camino 1994; Camino 1994) and intergenerational conflicts (e.g. Rumbaut 1996), which children of immigrants, and minority youth in general, face, have been reported widely.

Bourne (1997) emphasizes the agency of minorities, and expands the discourse with two fresh and important components: the role of imagined futures, as well as the role of global context in the process of cultural constructions. She states that minorities have to be seen "as people actively engaged in constructing new lives for themselves in a global context, integrating what they find valuable about their past lives within the possibilities open to them in the new" $(1997,14)$. The fact that one cannot fix the identities of minorities in 'heritage cultures' is especially true, according to Bourne $(1997,14)$, in the case of minority youth. She emphasizes that cultural mixtures produced by minority 
youth consist of global, national and local cultures and subcultures, which interact together and are fluid and everchanging ${ }^{6}$.

Hybridity, the cultural construction that draws on various influences, is a 'collective condition' (Werbner 1997, 12) - or rather a collective process - which concerns the adult population as well as youth. Boundaries are drawn and ethnicity is constructed in a collectively negotiated practice (see e.g. Barth 1969, Geertz 1973). Individuals belonging to the same ethnic group but having very different backgrounds socially, educationally, economically and so forth participate in this negotiation, and various claims, statuses and power positions are contested with one another. But youth seldom has a voice, or their voice is ambiguous, in these negotiations at the family and ethnic group level. Since adolescents usually proceed at a faster pace in the process of cultural construction/ethnic reconstruction, creating more radical forms of hybridity than adults do, their behavior is experienced as threatening the conceptions held by many adults. Werbner (1997) claims that hybridity in general is perceived as potentially threatening to one's sense of moral integrity, and is thus a source of argument and reflection?

Based on empirical evidence, it is claimed that the adult Somali population in Finland actively engages in the process of cultural construction/ethnic reconstruction, the construction of hybrid forms of culture, by drawing on their past experiences, current opportunities and future perspectives. They construct new ways of life in new environments and strive to be socially competent in contexts which they find meaningful and important for themselves. One aspect of this process is the active and at times heated discourse on what are the morally acceptable ways of behavior. This discourse usually concentrates on the issue of what is regarded by various individuals as conforming to Islamic values. Another aspect in the process of cultural construction is the question of who are the persons in a position to have a voice in saying what is right and acceptable and what is not. Since an important orientation and provider of guidelines for life in diaspora for Somalis in Finland was religion, the role of religious leaders in the process of cultural construction is recognized as being strong.

In the boundary talk and cultural construction discourse, one topic seemed to rise above the others among Somali adults: the situation of the adolescents. In the numerous seminars and meetings in which the situation of Somalis in Finland was discussed, Somali professionals, parents and various community leaders expressed their concern

\footnotetext{
${ }^{6}$ It is clear that most people, whether they are immigrants or not, engage in constructing their lives in a global and local context, integrating various components which are available to them. The distinction between non-immigrants and immigrants is that immigrants usually have a more diverse set of components for the construction of their new lives in a society, which is new and unfamiliar to them.

7 Turner (1967) refers in this respect to Mary Douglas' book Purity and Danger (1966) and her concept of pollution. Douglas holds that what from the perspective of social definitions is unclear or contradictory, is usually regarded as unclean, or polluting. In the same vein Turner points out that transitional beings are particularly polluting, since they are "betwixt and between" all recognized structural classifications.
} 
for young people. Also an uncountable number of discussions concerning these issues must have taken place in Somali homes. One religious leader said: 'Previously people used to talk about the situation in Somalia and returning there, but now they just talk about the children, ... about their concerns for their children.. People have become almost hysterical about the situation their children.'

In its most extreme form, this 'hysteria' was displayed through the actions of parents and caretakers who sent their offspring back to Somalia or to neighboring countries in order for them to be rescued from the bad effects of "westernization" 8 .

\section{Dissonant Acculturation}

Somalis expressed their concern for the ways in which cultural construction was taking place among the younger generation of Somalis. It did not seem to be cultural construction and change as such that concerned Somali parents and caretakers, instead it seemed to be the direction and speed of change among young people that created intergenerational conflicts. The desire of many Somali parents was that children should incorporate the 'good aspects' of life in Finland and simultaneously maintain their Islamic values.

Krulfelt (1992) claims that cultural construction is a creative process of innovation and reinterpretation, but in the case of refugees that process occurs more rapidly than for most other populations. Camino claims that for refugee adolescents the rapidity is not only due to refugee experience, but also to the nature of adolescence. She refers to Erikson (1968) and Schlegel and Barry (1991), according to whom the main task of adolescence is to form an identity. In the process of identity construction, many different kinds of influences in one's environment are used.

Portes (1997) defines the pattern when the first and second generations learn the ways of the new society at a different pace as "dissonant acculturation." He maintains that the rapid acculturation of the adolescents and the generational role reversal which often follows is unfavorable for the maintenance of parental authority: parents feel that they are 'losing' their children, meaning that they are no longer capable of controlling their offspring as they enter the complex society with all the risks it entails. Also Zhou (1997) maintains that dissonant acculturation severs ties between children and adults and deprives children of family and community resources which are crucial for example for their school performance.

\footnotetext{
8 The National Bureau of Investigation (Keskusrikospoliisi) examined the situation of 146 lost Somali minors, who had been granted a residence permit in Finland, but whose place of residence and living conditions were unknown to the authorities. In the final report of January 22, 2001, the majority of the parents or caretakers of those 51 minors who were known to have been sent back to relatives in Somalia, or to Kenya, Ethiopia, Saudi-Arabia or Egypt, maintained that the reasons for a child's move were related to their development milieu. Particularly in the cases of teenage Somalis, by sending a young person away the parents or caretakers wanted to ensure that his/her schooling, learning of manners and development milieu would conform to parents' own culture and religion. In addition, there were 32 children whose whereabouts remained unknown, but who had most probably moved abroad with their families or to join their siblings. (Keskusrikospoliisi 2001)
} 
The opposite pattern could be achieved if the parents acculturated at the same speed as their children or if the process among the adolescents is slowed down by the influence of the coethnic community. This last path, "selective acculturation" (Portes 1997,816; see also e.g. Gibson 1989) is associated with more positive outcomes than role reversal. In Helsinki, one way of slowing down the acculturation process which was employed by some Muslim parents was to put their children in an Islamic school in Helsinki'. Some others just tried to restrict their children from socializing with their Finnish peers too much.

In Finland, the very restricted access to the labor market of Somali adults, combined with xenophobia, prejudice and racism in the society, effectively denied the first generation access to the mainstream and thus hindered them from receiving positive influences for the process of cultural construction in a new environment. ${ }^{10}$ However, also the diasporic consciousness and the processes of boundary creation (Barth 1969) within the ethnic group, certainly to some degree related to negatively experienced encounters in the Finnish society, hindered the flow of influences, as well (Forsander 2000).

Thus, children and adolescents were in a different position from adults in terms of their contact with mainstream influences: through their participation in the school system, adolescents generally received more mainstream influences than the first generation ${ }^{11}$. In general, many Somali parents valued formal education, but their relation to the Finnish school was somewhat ambivalent, since the influences their children adopted in school in the form of a hidden curriculum, conflicted sometimes severely with the views of the parents. A comment of a father of many children reflects not only this commonly held ambivalence toward Finnish schools, but also the instrumental value of schooling, as well as his diasporic consciousness:

"Somalis should return to their country, otherwise children forget their culture. It is not good for them... The majority, almost all Somalis want to return. Meanwhile,

\footnotetext{
9 The number of Somali children in Islamic school was still low. One reason for this was certainly the fact that the Islamic school did not receive any financial support from the state, and hence, parents, many of them on a living allowance, had to pay a school fee. An imaam of one of the Mosques emphasized that Somalis should be given a chance to run some other institutions, such as youth homes, by themselves, as well, in order to ensure a socialization process that is in accordance with their cultural and religious vimalues.

${ }^{10}$ Due to the economic recession in Finland, the unemployment situation for the whole population deteriorated quickly in the 1990s, reaching 20 percent in 1994 (Statistics Finland 1999). For immigrants, the employment situation was especially difficult, and Somalis were hit the hardest. In 1994 the unemployment rate among working-age Somalis was 92 percent. One obstacle for Somalis in finding employment was, according to data, the lack of transferable skills and credentials needed in the Finnish labor market. Moreover, the Finnish labor market had a limited supply of entry-level jobs for non-Finnish speakers. When these factors were combined with the recession, prejudice and xenophobia in the labor market, it was practically impossible for Somalis to find employment during the early 1990s. This created a vicious circle that was hard to break: language skills did not develop without contact with the Finnish-speaking population, contacts with the mainstream were difficult to develop outside of the work environment and employment was not available without language skills. However, by the late 1990s, the employment situation had improved somewhat.

11 Dissonant acculturation and role reversal is supposedly also more prevalent in cases of unaccompanied minors, who enter the country years before their parents, compared to minors who enter the country simultaneously with their family members.
} 
before return is possible, people should learn, they should have an education. They should learn new things in order to help their country... But people should take only education in schools, not the other part that comes along with it - going with white ladies, gamble and drink - they should just take the education."

\section{Intergenerational conflicts: 'Young Princes on White Horses'}

Intergenerational conflicts mostly occurred between parents/caretakers and their adolescent sons ${ }^{12}$. The reasons for the conflicts were usually related to the claims made by sons for greater 'freedom' (e.g. having their own money/more money, late homecoming hours) and to the demands by the parents/caretakers for better respect and unquestioned obedience from the children.

Yusuf* was sixteen years old and the oldest son in his family. He attended a separate immigrant class of an upper comprehensive school after arriving in Finland as an unaccompanied minor. Not until after waiting for several years for the bureaucratic process of family reunification to come to a conclusion, was he able to get his entire family - about ten family members - to Finland. When the rest of the family eventually entered the country, he assisted his family members with many practical matters in their contacts with Finnish society. His father had worked for the military in Somalia, and had no chances for employment in Finland without some kind of a re-education. His mother was illiterate, and mostly stayed at home caring for Yusuf's younger siblings.

Quite often Yusuf had to be absent from school because he was running errands for his family. He was a street-wise young man, who was constantly tired and sleepy in school and had a hard time concentrating on school work. Towards the end of his last term in comprehensive school, his absences became more frequent. He was not only absent from school, but also increasingly spent nights away from home so that his parents went for many days not knowing where he was.

At the parents' meeting Yusuf's father gave a long monologue, echoing the concerns of many Somali parents: their fear of losing control over their children and the perceived conflict between the views of Finnish authorities and Somali parents on the role and status of children.

Yusuf's father says that Somali families have a difficult time in Finland, since parents are not respected in the way they used to be in Somalia. He takes an example: '[...] if a child asks for money for a bicycle worth sixteen hundred marks, and the parents say that they don't have the money for something like that because there

\footnotetext{
* The name is a pseudonym.
}

12 Sons and daughters in Somali families are not always biological offspring of the parents. Social parenthood has been widely practiced in Somalia and thus non-biological children have moved with the rest of the family even to Finland. In diaspora, there are also many new family constellations; 'new families' which have been formed due to divorees, lost or deceased spouses or new children who have been adopted by a family. Out of these new children, some may be unaccompanied minors who reside in a family temporarily while waiting for family reunification, or they may be children who have entered the country with a family as family members but actually using a wrong identity. Authorities and some Somali adults claim that the most severe intergenerational conflicts arise with the adolescents who have not lived with that particular family already in their homeland. 
are more important things to buy, the child may go to the social office and say that his parents won't give him anything and then the social office will buy him the bicycle. But if the parents ask for money for something they need, they are not given anything. This is how it works in this society: children's needs are respected, not those of the adults.'

The father explains that in Somalia even the President respected his father and the father might even hit his son, the president. As he recalls, in Somalia parents are always respected. He continues by telling how he was once fetching his son from the police station and hit his son although a policeman was present. The policeman had told him that what he had done was against Finnish law, but, the father explained, he wanted to show that 'children have to respect their parents even in this country.' He continues by saying that earlier when the children were younger, it was easier to make them obey their parents and teachers, but now they are older and they think that they are adults and they think they can do whatever they want.. 'They are like princes on white horses and nobody can stop them now.'

The father goes on to say how difficult it is for Somali men here since they are unemployed. In Somalia, he says, they used to learn respect by being the ones who brought money home. But he emphasizes that it is the mothers who have the most difficult time because they are so worried about their children. He says that he is worried about Yusuf, too. Numerous times he had been in the city center of Helsinki looking for his son during the periods when he did not show up at home for many days. And the father is concerned for the younger sons, as well, since he believes that a good example set by the oldest son is particularly important for the younger ones.

The critical issue in the relation of parents/caretakers and adolescents was related to discipline and respect. In a patrilineal kinship system, in which children are expected to make the family stronger and to provide economic security for aged parents, parental respect and obedience is highly valued. Children, particularly sons, are also expected to bring strength and honor to a man and his lineage and a father has absolute right to custody of all his children (Lewis 1994). In some cases, Somali parents felt that the realization of these principles was threatened, as the strong Scandinavian-style welfare state competed for the "ownership" of the children ${ }^{13}$.

Due to the role reversal between adults and children, parents and caretakers feared loss of authority; they feared that children would lose respect for their parents and become

\footnotetext{
13 In some extreme cases, intergenerational conflicts led to the involvement of authorities in issues that in Somalia had traditionally been private concerns of the family and kin. The collision of the conceptions of a strong welfare state and the Somali kinship system on issues in which the very core was the culturally bounded questions of what is the 'best interest of a child' and who has the ultimate 'ownership' of a child. In these collisions, sometimes manipulated by the teenagers themselves, some of them ending up in an ambiguous liminal state between their parents/caretakers and the authorities. In the name of "the best interest of a child, " authorities sometimes got involved in the lives of Somali families in cases concerning intergenerational conflicts. Depending on the authorities' view on how severely the best interests of a child were threatened, they sometimes took a child into custody. These cases were rather extreme examples of intergenerational conflicts, and often occurred with teenagers who had not lived with these particular family members in Somalia. Teenagers (as well as parents) found themselves 'betwixt and between' the strong welfare state and the traditional kinship system. In extreme cases, adolescents themselves took advantage of their liminal status between the family and authorities and purposefully manipulated the situation so that they were transferred by authorities to a youth home where they believed more 'freedom' prevailed.
} 
disobedient. This would be the worst possible thing that could happen to a Somali parent. Expecting respect and obedience from children also conformed to Islamic values, and thus this demand was often grounded in religion. A religious leader expressed the severity of lost parental respect and obedience by saying: "According to Quaran, at the time of Judgment, if I can't control my son, I'll be sinful."

The involvement of authorities in cases of intergenerational conflict within families was difficult for the parents to understand and to accept also due to their understanding that intergenerational conflicts were a family concern and children were an unquestioned part and possession of the kin. In the same vein as what was heard in the accounts of many parents in the Helsinki metropolitan area, Berns McGown (1999) reports the fears of Somali parents in London and Toronto of losing their children and their frustration over their inability to discipline their children due to their concern that children would call emergency numbers if the parents infringed on their freedom ${ }^{14}$.

Drawing this chapter together, it has been claimed that many Somali youth may find themselves in a state of liminality which is due to their status in the process of cultural construction/ethnic reconstruction. The way and pace in which they construct new hybrid cultural forms is often experienced as threatening by the Somali adult population. The status of youth in the family and within their ethnic group does not allow them to participate in the definition of the norms for appropriate cultural construction/ethnic reconstruction. Still, due to the dissonant acculturation, the roles of parents and adolescents were often reversed, since adolescents needed to guide their parents and caretakers in the new society. Thus, youth found themselves 'betwixt and between' various roles of having power and not having it. Additionally, as an extreme consequence of role reversal in some Somali families, adolescents and parents/caretakers may find themselves in between the differing conceptions of a strong Finnish state structure and those of the Somali patrilineal kinship system.

\section{Transnational and diasporic consciousness and the ethos of "integration"}

\section{The Ethos of 'Integration'}

In the previous chapter, one form of liminality of Somali youth, that related to their role and status in the process of cultural construction/ethnic reconstruction, was presented. In this chapter, another form of liminality is presented. It is maintained that many Somali young people are situated in between the diasporic and transnational consciousness of their ethnic group and the ethos of 'integration' (often connected with assimilative practices) of the receiving society. This chapter discusses the ethos within the receiving

14 The same fears have been reported also by e.g. Bartels (2000) concerning Moroccan parents in Dutch society. 
society, where the expectation and point of departure in the reception of immigrants is their 'integration'. The data collected through the school ethnography shows, however, that many Somali young people as well as adults live in a transnational and diasporic context, in which future perspectives other than integration with the Finnish society are considered as at least equally desirable alternatives. The way in which the diasporic consciousness of the adolescents is reflected in the context of formal education and imagined futures is described in this chapter.

The 'integration' of immigrants and refugees (kotoutuminen) has become a mantra of Finnish authorities involved with the reception and acculturation of immigrants and refugees. Officially, integration has been defined to mean "... 1) the personal development of immigrants, aimed at participation in work life and the functioning of society while preserving their language and culture; and 2) the measures taken and resources provided by the authorities to promote such integration"15. As the central involvement of the Ministry of Labor and local employment authorities in the planning and implementation of integration measures indicates, integration basically and concretely means a process through which an immigrant is supposed to take part in working life so that he/she can support him-/herself and his/her family in the Finnish society. ${ }^{16}$

Based on the ethos of 'integration' of immigrants and refugees, the practices within various executive offices and of authorities (including e.g. schools and teachers) seemed to be geared solely towards integration into Finnish society. However, empirical findings indicate that integration of adult Somalis was not very successfull and it was not the only option among the future perspectives of Somali refugees residing in Finland. It is claimed that the notion of 'integration' is insufficient in describing the desired future perspectives held by Somalis in Finland. In this situation of the simultaneous existence of the transnational and diasporic consciousness of Somalis with the ethos of integration of the receiving society may be confusing. Youth, in particular, may find themselves in a liminal position, being in between two, or even more, imagined futures. In a situation of imagined lives in two or more alternative societies simultaneously, they find themselves in a liminal state which can be characterized as being "... a realm that has few or none of the attributes of the past or coming state" (Turner 1967, 94).

Although the Finnish authorities in the case of the Somali refugees seemed to have largely forgotten the ultimate goal of refugee reception, defined by United Nations High Commissioner for Refugees (UNHCR) as supporting the repatriation of refugees, Somali refugees in Finland have largely maintained repatriation as their own ideal. The

15 Definition in The Act on the Integration of Immigrants and Reception of Asylum Seekers (Number 493/1999, Section 2).

16 There is a clear assimilative content that is connected with the concept of "integration." Although the official discourse on integration stresses also the importance of "preserving one's own language and culture" and the adjustment from both sides, both by the minority and the receiving society, the preposition used with the term 'integration' is revealing: instead of 'integration with Finnish society and working life,' a frequently used form e.g. in official documents is 'integration into Finnish society and working life'. 
myth of return has been kept vividly alive in Somali communities, despite the longlasting civil war and the prevailing chaos in Somalia.

\section{Transnational practices}

Transnationalism refers to processes whereby immigrants and refugees "forge and sustain multi-stranded social relations that link together their societies of origin and settlement" (Basch, Glick Schiller and Szanton Blanc 1994,7). A wider definition, which is applied in this article, includes the maintenance of familial, economic, political and cultural ties beyond national borders which are not limited only to societies of origin and settlement, but extend even to other societies were people of diaspora live.

Transnational practices were frequent among Somalis in Finland, including, for example, contacts with other diaspora Somalis in other countries by phone, email, mailed videotapes, internet websites and visits (Alitolppa-Niitamo 2000).

Transnational contacts were vital in keeping in touch with relatives and balancing resources. For example, over summer vacation, some school children and adolescents were sent to visit their relatives in other diaspora countries in Europe. In a few cases, small children were sent to relatives in other European countries in order to be taken care of temporarily when a new baby was born in the family or if the mother was for some other reason unable or too busy to care for all her children.

Transnational contacts among diaspora Somalis also provided important information about conditions in other countries, about employment and educational possibilities, for example. An increasing trend among Somalis in Finland towards the beginning of the new millennium was to travel to other European countries, particularly to London, to look for better employment opportunities. According to one community leader, out of the adult Somalis who had received Finnish citizenship, enabling them to move freely in EU-countries, thirty percent had left Finland. Although this figure is certainly exaggerated, and more likely indicates the percentage of educated adult males who had left the country, at least temporarily, it reflects the transnational nature of Somali diaspora in Finland: having their feet in two, perhaps even more societies simultaneously.

\section{The Diasporic Consciousness}

It is also claimed in this article that Somalis have a diasporic consciousness that connects them closely with their homeland. The concept diaspora is used in the meaning defined by William Safran (1991) and it is maintained that this is a highly accurate description of the majority of Somali adults residing in Finland. Following Safran's definition, the Somalis can be characterized as forming an expatriate minority community that regards its ancestral homeland as the true and ideal home and that retains the homeland in a collective memory and myth. They continue to relate to the homeland, they feel solidarity towards it and envision an eventual return in the event that condi- 
tions there make return feasible. The idea of return may be enhanced by the fact that they believe that they are discriminated against, and therefore feel partly alienated and insulated from their host country. For Somalis, as for diaspora communities in general, the relationship to their homeland is essential to their "ethnocommunal consciousness" and their sense of solidarity.

In the following, some ethnographic examples of discussions on how the homeland is represented by Somali adolescents in relation to formal education and imagined futures are reported. It was found that from the viewpoint of Somali adults, the meaning of formal education, which is supposed to be "integrative" according to the Finnish authorities, is often considered to be of instrumental value and connected with the idea of return.

Somali youth expressed their views related to formal education and repatriation in various manners. A boy studying in a vocational school said: 'Education is important. Well, Anne, you know, I need to help my own country. I need to participate in the rebuilding of it.' He said this when he was about to change schools because of difficulties with a teacher. He decided, however, to continue struggling in his old school since the change would have caused delays in his studies. The father of this boy had a strong diasporic consciousness, and he made his life in exile meaningful by participating in projects that would benefit his 'homeland.' The father had re-educated himself and planned to return within a couple of years. In his actions he showed solidarity toward his homeland, and the following comment by the father reflects the experience of discrimination and insulation in Finland. He says 'It is important for the children to know that they have a country, a place that is theirs, here they will always be just 'refugees'.

All young Somalis did not directly express feelings of loyalty towards Somalia, but in their individual choices concerning their future profession, Somalia was the framework in their minds: occupations which would have applicability in Somalia were clearly preferred. In one classroom where students were talking about choosing among the various departments in a vocational school, one boy suggested to another one: "Let's choose the transportation department, then we can establish a transportation business between Somalia and Kenya. In that branch, there will be a lot of possibilities available. "Later the same boy changed his mind and was considering getting an education in the navy and later getting involved with ships sailing between Yemen and Somalia. ${ }^{17}$

Some teenagers had more divided loyalties to their homelands and their host countries such as a boy 16 years of age both of whose parents were also being educated in Finland: "I will first receive an education here, and then I'll work here for sometime,

${ }^{17}$ Knocke and Hertzberg (2000) report on the diasporic orientation of Turkish young women in Sweden who by choosing tourism as their future occupation kept the door open to their homeland. Also Schierup and Ålund (1987) describe how among two groups of Yugoslav immigrants in Scandinavian, the Wallachiansin Sweden and the Macedonians in Denmark, parents tried to channel their children into occupations which they believed could be used in the villages of origin. 
and, if there is peace in Somalia, I'll move back there." A young man, 21 years of age, who is more doubtful about opportunities in Somalia, says: "The idea of returning and working in Somalia is OK. I might consider that option, if there was peace there. But there is one practical problem: there are no employers there, who is going to pay your salary in Somalia?"

Of course, the return to one's homeland does not need to be the definite goal for a person with a diasporic consciousness. Other aspects that illustrate the diasporic consciousness of Somali adults were, for example, sending remittances to relatives in Somalia, building a house there, claiming one's previously owned land back and engaging in rebuilding activities in Somalia through various associations and networks.

Dispersion of human resources has been found to be an important surviving strategy in many communities with limited material resources (e.g. Chan 1997). The role of relatives living in other countries and the remittances they send have always been of great importance in Somalia (Rousseau, Said, Gagné and Bibeau 1998). For example, some young Somali adults in Finland, already established professionally in Finnish society, can be said to have a diasporic consciousness even though they did not view return as realistic or reasonable: they had frequent contact with their homeland and other diaspora communities, some of them had visited Somalia, and out of their sense of solidarity and norms related to assistance of kin in need $\left(\right.$ Quaraan $\left.^{18}\right)$, they frequently sent remittances. ${ }^{19}$

Neither transnational ties nor diasporic consciousness should be seen as necessarily impeding the integration process, but as Foner (1997) maintains, these ties could be seen as complementing commitment to the resettlement country. For example, while many of the Somali adults in Finland engaged in transnational networks and even imagined their future in Somalia, some of them simultaneously showed intensive involvement, for example, in educational achievement in Finland, which, if a repatriation would not be realized, will enhance one's integration with Finnish society.

Even if diasporic ties and activities may, in some cases, be based on a romanticized, idealized and purified idea of the homeland or even if they serve as a way of escapism from prejudice, xenophobia, racism or marginalization in the resettlement country (Foner 1997), these ties and activities give a sense of belonging and connectedness and they may also create and keep up optimism and positive future perspectives. This is essential for the maintenance of one's mental health and activity level in exile. (also Shuval 2000)

18 Quaraan is a traditional system of assistance where money is collected selectively and given out within the subclan /clan family for the purpose of covering unexpected expenses. One cannot refuse to give assistance if it is asked for (Simons 1992).

${ }^{19}$ For example, in Somaliland, the self-claimed new state in the northwest of Somalia, remittances from diaspora countries are the second most important source of income, next to income from livestock exports (International Organization for Migration 2000). 
The imagined futures in the homeland or in other more desired diaspora societies may encourage and motivate the adult population to advance their education. The situation of adolescents is more complicated. Transnational or diasporic consciousness may encourage the younger generation, although perhaps to a lesser degree than adults, but it may, as Portes (1997) claims, complicate their course of adaptation. The younger generation may, as the examples above show, have a diasporic consciousness which is encouraged by the parents. Simultaneously, however, due to the major influences of 'the ethos of integration' of the receiving society and its institutions, the younger generation becomes increasingly, and in a faster manner than adults, integrated into Finnish society.

\section{Summary}

This article presented some aspects that the author sees as creating dilemmas in the lives of many Somali youth in the Helsinki metropolitan area. Particularly young Somalis, "the generation in-between", who were in their teens or early teens at their arrival in Finland in the 1990s are seen as finding themselves 'betwixt and between' various statuses, roles and options for the future. In the article two challenges facing youth have been described: (1) the role of Somali youth in their families in the process of cultural construction/ethnic reconstruction, and (2) the position of Somali youth in between the diasporic consciousness of their families and the ethos of 'integration' in the receiving society. It is asserted that these challenges place young Somalis in a position of liminality. How they overcome these challenges depends much on social relationships available for them. The social capital (see Zhou 1997) in a form of social support and social control provided by Somali families depends much on how these families have been able to stay intact and functional in the turmoil of refugee experience. Also the tolerant atmosphere and the supportive measures and relationships within the receiving society are of major importance.

Liminalities are transitional phases, in which an individual is detached from previous statuses, norms and definitions while not yet being anchored into new ones. In this article it is suggested that in a phase of liminality one's options may be expanded, but too many forms of simultaneous liminalities may even be confusing and may constrain a person from finding an appropriate group of reference. Many simultaneous liminalities may ultimately lead to marginalization from existing societal and cultural classifications. Adolescence as such is already a state of liminality in which a person is in transition from childhood to adulthood. The status of being a refugee in a new society is another such state of liminality.

The assertion is made that while the entire Somali community is in the process of cultural construction and ethnic reconstruction, the position of youth is often ambiguous 
and they seldom have a voice in this process. Through their intense contact with educational institutions and peer groups, young people acquire new influences, which often lead to dissonant acculturation and intergenerational conflicts in their families. Due to their better knowledge of the Finnish language and understanding of the functions of Finnish society, the roles in the families may become reversed, particularly in contacts with the mainstream society.

Intergenerational conflicts are frequent within many ethnic groups which have migrated. More research would be needed on the factors that contribute to severe intergenerational conflicts in families with an immigration or refugee background. Factors which seem to contribute to role reversal and dissonant acculturation in the case of Somali families in Finland formed a complex combination of many obstacles for the adult population in creating contacts with the mainstream society (for example, the parents' low educational level, prejudice in the society, lack of employment opportunities) and a small and internally divided ethnic group. Finding a good functional level of parental authority is a challenge for all parents, but this is especially true for many ethnic minorities.

In order to balance the pace of the acculturation process between the first and second generation, social policy, educational and employment measures should be applied in order to enhance the adult population's possibilities to create more contacts with the mainstream society. Ethnic groups should also be supported and should be internally strong enough to provide the young generation alternatives for the integrative activities of the mainstream society. In terms of formal education, a balance in enhancing youth's sense of ethnic identity and introducing the ways of the new society should be achieved.

The position of Somali youth in between the diasporic and transnational consciousness of the Somali communities and the ethos of integration of the host society has been described as another factor that may place this generation in an ambiguous situation. Many adult Somalis have future perspectives in which options other than integration with Finnish society are at least equally desired alternatives. Returning to one's homeland or moving to another diaspora country are valid options for many adults, while young people are increasingly subject to integrative (often assimilative) processes in the educational institutions they are attending. Young persons are seen here to be in a liminal position, in which various forces draw them in different directions.

Diasporic consciousness is common particularly for refugees, who have been forced to leave their homeland. Among Somalis, particularly during the first years of diaspora, the idea of repatriation as soon as the circumstances in Somalia would allow it, was widely kept alive. Particularly for the older generation, who faced great difficulties in finding employment in a new society and who experienced a large discrepancy in their past and current statuses, the diasporic consciousness seemed to be more prevalent than for the young adults. For many, the transnational option of moving to some other 
diaspora country was a valid alternative, as well. Gradually, as the acculturation process proceeded, the option of staying was allowed more room in perspectives for the future. The consequences for young people of liminality, created by the diasporic consciousness and the transnational options of the adult population and the ethos of integration in main stream educational institutions, is a topic that should be studied more closely. The understanding and acceptance of the diasporic consciousness of refugees should be taken into consideration, for example, in the planning of educational programs and vocational training.

\section{References}

Aallas; Esa 1991. Somalishokki. (Somali Shock). Suomen pakolaisavun julkaisusarja 2. Jyväskylä: Gummerus.

Abu-Lughod, Lila. 1991. Writing against Culture. In: Recapturing Anthropology: Working in the Present, edited by R. Fox. Santa Fe, New Mexico: School of American Research Press.

Alitolppa-Niitamo. 1994. Somali Refugees in Helsinki. Focus on Social Networks and the Meaning of Clan Memebership. Ministry of Social Affairs and Health, Reports 1994:11.

- 2000. From the Equator to the Arctic Circle. A Portrait of Somali Integration and Diasporic Consciousness in Finland. In: Rethinking Refuge and Displacement. Selected papers on Refugees and Immigrants, edited by E.M. Gozdziak and D.J. Shandy, vol. viii. Arlington, VA: American Anthropological Association.

Alitolppa-Niitamo, Anne and Abdullahi Ali. 2001. Somalidiaspora Suomessa - muutoksia, haasteita ja haaveita. (Somali Diaspora in Finland - Changes, Challenges and Dreams) In: Monietnisyys, yhteiskunta ja työ, edited by Annika Forsander, Elina Ekholm, Petri Hautaniemi, Abdullahi Ali, Anne Alitolppa-Niitamo, Eve Kyntäjä and Quoc Cuong Nguyen. Helsinki: Palmenia-kustannus.

Amit-Talal, Vered. 1995. Conclusion: The multi-cultural youth. In: Youth cultures. A crosscultural perspective, edited by V. Amit-Talai and H. Wulff. New York: Routledge

Bartels, Edien. 2000. "Dutch Islam": Young People, Learning and Integration. Current Sociology 48(4):59-74.

Barth, Fredrik. 1969. Introduction. In: Ethnic Groups and Boundaries. The Social Organization of Cultural Difference, edited by F. Barth, pp. 9-38. London: George Allen \& Unwin.

Basch, Linda, Nina Glick Schiller and Christina Szanton Blanc. 1994. Nations Unbound: transnational projects - postcolonial predicaments and deterritorialized nation-states. Basel: Gordon and Breach Science Publishers SA.

Berns McGown, Rima. 1999. Muslims in the Diaspora. The Somali Communities in London and Toronto. Toronto: University of Toronto Press Incorporated.

Bourne, Jill. 1997. Teaching and Learning in a Multicultural Context. Paper presented at the International Congress on Multicultural Education. Jyväskylä Finland 16.-18.10.1997.

Caglar, Ayse S. 1997. Hyphenated Identities and the Limits of 'Culture.' In: The Politics of Multiculturalism in the New Europe, edited by Tariq Modood and Pnina Werbner, pp.169185. 
Camino, Linda A. 1994. Refugee Adolescents and Their Changing Identities. In: Reconstructing Lives, Recapturing Meaning. Refugee Identity, Gender and Culture Change, edited by Linda A. Camino, and Ruth M. Krulfeld. Basel, Switzerland: Gordon and Breach Publishers.

Chan, Kwok Bun. 1997. A Family Affair: Migration, Dispersal, and the Emergent Identity of the Chinese Cosmopolitan. Diaspora, 6(2):195-213.

Caputo, V. 1995. Anthropology's silent 'others'. A consideration of some conceptual and methodological issues for the study of youth and children's cultures. In: Youth cultures. A cross-cultural perspective, edited by V. Amit-Talai and H. Wulff. New York: Routledge.

Clifford, James. 1988. The Predicament of Culture: Twentieth Century Ethnography. Literature and Art. Cambridge: Harvard University Press.

Conzen, K.D., E. Gerber, G. Morowska, and R. Vecoli. 1992. The Invention of Ethnicity: A Perspective from the U.S.A. Journal of American Ethnic History, 12:3-41.

Douglas, Mary. 1966. Purity and Danger. An analysis of the concepts of pollution and taboo. New York: Routledge.

Erikson, Erik H. 1968. Identity, Youth and Crises. New York: W.W. Norton and Company

Fischer, Michael M.J. 1986. Ethnicity and Post-Modern Arts. In: Writing Culture: The Poetics and Politics of Ethnography, edited by James Clifford and G.E. Marcus, pp. 19-233. Berkeley: University of California Press.

Foner, Nancy. 1997. What's New about Transnationalism? New York Immigrants Today and at the Turn of the Century. Diaspora, 6 (3):355-375.

Forsander, Annika. 2000. The Ethnic Radicalization of Somalis in Finland. A paper presented at the EUROFOR-Conference in Jerusalem, January 20-23, 2000.

Gans, Herbert J. 1997. Toward a Reconciliation of "Assimilation" and "Pluralism": The Interplay of Acculturation and Ethnic Retention. International Migration Review 31(4):875-892.

Geertz, C. 1973. The Integrative Revolution: Primordial Sentiments and Civil Politics in the New States. The Interpretation of Cultures, pp. 255-310. New York: Basic Books.

Gibson, M.A. 1989. Accommodation without Assimilation: Sikh Immigrants in an American High School. Ithaca, NY: Cornell University Press.

Glick Schiller, N., L. Basch and C. Szanton-Blanc. 1992. Transnationalism: A New Analytic Framework for Understanding Migration. In: Towards a Transnational Perspective on Migration: Race, Class, Ethnicity and Nationalism Reconsidered, edited by N. Glick Schiller, L. Basch and C. Szanton-Blanc. New York: Academy of Sciences.

International Organization for Migration. 2000. Nordic conference on Somaliland. November 23-24.1999, Helsinki Finland. IOM-Helsinki Report 25/00.

Keskusrikospoliisi. 2001. Somalialaissyntyisten lasten ja nuorten katoamiset Suomessa 1993 2000. Julkinen raportti. Rikostietopalvelu, Laittoman maahanmuuton käsittelyryhmä. Tutkimus- ja tietopalvelu. (National Bureau of Investigation: Disappearances of Somali-born children and youth in Finland in 1993-2000).

Knocke, Vuokko and Fredrik Herzberg. 2000. Mångfaldens barn söker sin plats. En studie om arbetsmarknadschanser för ungdomar med invandrarbakgrund. (The Children of Multiplicity Looking for Their Place. A Study of the Opportunities in the Employment Market for the Youth with Immigration Background). Stockholm: Svartvitts Förlag.

Krulfeld, Ruth M. 1992. Cognitive Mapping and Ethnic Identity. The Changing Concepts of Community and Nationalism in a Laotian Diaspora. In: Selected Papers on Refugee Issues, edited by Pamela A. DeVoe. Arlington, VA: American Anthropological Association.

- .1994. You Can't Go Home Again: Personal Experiences of Marginalization, Liminality, and Metamorphosis in Long-Term Local Fieldwork on Refugees. In: Selected Papers on Refugee Issues: III, edited by Jeffery L. MacDonald and Amy Zaharlick. Arlington,VA: 
American Anthropological Association.

Krulfeld, Ruth M. and Linda A. Camino. 1994. Introduction. In: Reconstructing Lives, Recapturing Meaning. Refugee Identity, Gender and Culture Change, edited by Linda A. Camino and Ruth M. Krulfeld. Basel, Switzerland: Gordon and Breach Publishers.

Lewis, Ioan M. 1994. Blood and Bone. The Call of Kinship in Somali Society. Lawrenceville, N.J.: The Red Sea Press.

Malkki, Liisa H. 1995. Purity and Exile. Violence, Memory, and National Cosmology Among Hutu Refugees in Tanzania. Chicago: The University of Chicago Press.

Rotheram, Mary J. and Jean S. Phinney. 1991. Introduction: Definitions and Perspectives in the Study of Children's Ethnic Socialization. In: Children's Ethnic Socialization. Pluralism and Development, edited by Jean S. Phinney and Mary J. Rotheram. Newbury Park, California: Sage.

Portes, Alejandro. 1996. Introduction: Immigration and Its Aftermath. In: The New Second Generation, edited by A. Portes. New York: Russell Sage Foundation.

--. 1997. Immigration Theory for a New Century: Some Problems and Opportunities. International Migration Review 31(4):799-824.

Rousseau, Cécile, Taher M. Said, Marie-José Cagnè and Gilles Bibeau. 1998. Between Myth and Madness: The Premigrant Dream of Leaving Among Young Somali Refugees. Culture, Medicine and Psychiatry 22(4): 385-411.

Rumbaut, Ruben G. 1996. The Crucible Within: Ethnic Identity, Self-Esteem, and Segmented Assimilation among Children of Immigrants. In: Alejandro Portes (ed.). The New Second Generation. New York: Russell Sage Foundation.

Safran, William. 1991. Diasporas in Modern Societies: Myths of Homeland and Return. Diaspora 1(1):83-99.

Schierup, Carl-Ulrik and Alexandra Alund. 1987. Will They Still Be Dancing? Integration and Ethnic Transformation Among Yugoslav Immigrants in Scandinavia. Stockholm: Almqvist \& Wiksell International.

Schlegel, Alice and Herbert Barry. 1991. Adolescence. An Anthropological Inquiry. New York: The Free Press.

Shuval, Judith T. 2000. Diaspora Migration: Definitional Ambiquities and a Theoretical Paradigm. International Migration, 38(5):41-58.

Simons, Anna. 1992. Networks of Dissolution in Somalia. Ann Arbor, MI: UMI.

Statistics Finland. 2000a. Suomalainen lapsi. (The Finnish Child). Väestö 2000:7. Helsinki.

—. 2000b. Väestörakenne 1999 (The Population Structure 1999). Väestö 2000:8. Helsinki.

— 2000c. Ulkomaalaiset ja siirtolaisuus. (Foreigners and Migration). Väestö 2000:10. Helsinki.

Turner, Victor. 1967. The Forest of Symbols. Aspects of Ndembu Ritual. London: Cornell University Press.

- 1977. Variations on the Theme of Liminality. In: Secular Ritual, edited by Sally Falk Moore and Barbara G. Myerhoff. Assen/Amsterdam: Van Gorcum.

Werbner, Pnina. 1997. Introduction; The Dialectics of Cultural Hybridity. In: Debating Cultural Hybridity. Multi-Cultural Identities and the Politics of Anti-Racism, edited by Pnina Werbner and Tariq Modood. London: Zed Books.

Wulff, Helena. 1995. Introduction: Introducing youth culture in its own right: the state of the art and new possibilities. In: Youth Cultures. A Cross-Cultural Perspective, edited by V. Amit-Talai and H. Wulff. London: Routledge.

Zhou, Min. 1997. Segmented Assimilation: Issues, Controversies, and Recent Research on the New Second Generation. International Migration Review 31(4):975-1008 